\title{
Ruch Narodowo-Socjalistyczny (NSB) w Niderlandach i jego koncepcja polityki zagranicznej w latach 1931-1945
}

Historia Niderlandów w okresie II wojny światowej jest zagadnieniem nie mniej złożonym niż historia innych państw europejskich. Oprócz otwartej walki zbrojnej, działalności podziemnej i biernego oporu społeczeństwa w kraju tym występowały także postawy obojętności wobec sytuacji politycznej, oportunizm oraz różne stopnie aktywnej współpracy z okupantem. Być może najlepiej znanym ugrupowaniem politycznym identyfikowanym z kolaboracją jest Ruch Narodowo-Socjalistyczny (Nationaal-Socialistische Beweging, NSB), którego geneza sięga okresu przedwojennego ${ }^{1}$. Sprowadzenie tej formacji do prostej ekspozytury niemieckiej partii nazistowskiej byłoby wszakże nadmiernym uproszczeniem, zaciemniającym skomplikowany charakter skrajnie prawicowej części holenderskiej sceny politycznej przed wojną i w trakcie wojny. Niezależnie jednak od skali inspiracji zagranicznymi źródłami faszyzmu i nazizmu NSB był partią wywodzącą się z Niderlandów i prezentującą $\mathrm{w}$ rozmaitych kwestiach inne poglądy niż NSDAP lub niemiecki rząd. Było to szczególnie widoczne w odniesieniu do spraw międzynarodowych i polityki zagranicznej.

Główna teza niniejszego artykułu głosi, że NSB w trakcie swojego istnienia wypracował własną koncepcję dotyczącą polityki zagranicznej. Była ona stosunkowo trwała, a pewne jej modyfikacje dokonywały się zarówno pod wpływem ewolucji układu sił wewnątrz Ruchu, jak i z racji zmieniających się okoliczności zewnętrznych. W celu udowodnienia tej tezy tekst został podzielony na pięć części. Pierwsza ma charakter ekspozycyjny i służy naszkicowaniu genezy, rozwoju i rozpadu formacji. Część druga zawiera podsumowanie pożądanego przez NSB

\footnotetext{
1 J. Balicki, M. Bogucka, Historia Holandii, Wrocław 1989, s. 375-376.
} 
kształtu porządku międzynarodowego, w tym kwestię Ligi Narodów oraz geopolitycznego położenia Europy. Część trzecia charakteryzuje preferowany system stosunków Holandii z najważniejszymi mocarstwami sąsiednimi - Niemcami, Francją i Wielką Brytanią — oraz omawia w ich kontekście projekt Związku Państw Germańskich. W części czwartej zostanie przedstawione podejście Ruchu do koncepcji wielkoniderlandzkiej oraz jego stosunek do „narodów pokrewnych”Flamandów i Afrykanerów. Część piąta charakteryzuje natomiast podejście NSB do kwestii polityki kolonialnej.

\section{NSB — geneza i rozwój}

Historia powstania i rozbudowy Ruchu Narodowo-Socjalistycznego wiąże się nierozerwalnie z osobą jego założyciela i „Wodza” (Leider) - Antona Musserta. Urodzony w 1894 roku, był z wykształcenia inżynierem melioracji, od 1920 roku zaś pracował jako urzędnik w okręgu wodnym w prowincji Utrecht ${ }^{2}$. Jego kariera polityczna rozpoczęła się w 1925 roku na fali protestów przeciwko podpisaniu traktatu belgijsko-holenderskiego, zmieniającego warunki separacji obydwu państw po wojnie $\mathrm{z}$ lat $1830-1839$.

Układ ten umożliwiał Belgii poszerzenie połączenia wodnego AntwerpiaMorze Północne, co dla Holandii było niekorzystne z gospodarczego punktu widzenia. Zezwalał także na nieskrępowany dostęp belgijskich okrętów wojennych do tego portu, co nacjonaliści po północnej stronie granicy interpretowali jako zagrożenie neutralności Niderlandów oraz pierwszy krok do zakwestionowania holenderskiej władzy nad Flandrią Zelandzką (terytorium położonym na południe od ujścia Skaldy) ${ }^{3}$. Biorąc pod uwagę belgijskie roszczenia terytorialne wobec północnego sąsiada, zgłaszane po zakończeniu I wojny światowej ${ }^{4}$, obawy te nie były całkowicie pozbawione sensu. Protesty zaś wobec traktatu mogły liczyć na stosunkowo szeroki poklask zaniepokojonej opinii publicznej.

Przyjęcie układu minimalną większością głosów przez holenderską Drugą Izbę stworzyło podatny grunt dla działalności organizacji skrajnie prawicowych. Mussert silnie zaangażował się w kampanię sprzeciwu i przy tej okazji wykazał się dużym talentem organizacyjnym. To między innymi dzięki kierowanej przez niego akcji propagandowej umowa została ostatecznie odrzucona w Pierwszej Izbie w 1927 roku. Niezależnie od korzystnej z prawicowego punktu widzenia

${ }^{2}$ Skrócona biografia zob. https://www.parlement.com/id/vg9fgopw85zk/a_a_anton_mussert (dostęp: 30.10.2017).

${ }^{3}$ L. Wils, De Groot-Nederlandse beweging, ,Tijdschrift over de Geschiedenis van de Vlaamse Beweging" 2005, nr 1, s. 30, 32.

4 J. Łaptos, Historia Belgii, Wrocław 1995, s. 213. 
konkluzji traktat, nazywany „wersalem dla Niderlandów”" i przedstawiany jako narodowa hańba, dla grup skrajnych nadal stanowił cenną trampolinę polityczną. Dalsze negocjacje belgijsko-holenderskie oraz zapowiedzi podpisania nowej jego wersji stały się bezpośrednim impulsem utworzenia NSB w grudniu 1931 roku$^{6}$.

Podobnie jak w innych krajach kryzys ekonomiczny stworzył dogodne warunki do rozwoju partii skrajnych. W 1931 roku powstała również Narodowo-Socjalistyczna Niderlandzka Partia Robotnicza (NSNAP), rok później — Powszechny Niderlandzki Związek Faszystów (ANFB), a w 1933 roku — Związek Odbudowy Narodowej (VNH) ${ }^{7}$. Ruch nie był zatem jedynym ugrupowaniem radykalnie prawicowym, okazał się jednak najbardziej skutecznym. W wyborach prowincjonalnych w 1935 roku NSB nieoczekiwanie uzyskał niemal 295 tysięcy głosów, co odpowiadało poparciu $7,9 \%$ elektoratu $^{8}$. Tym samym stał się piątą siłą polityczną w kraju, jego liczebność zaś osiągnęła 36 tysięcy członków ${ }^{9}$. Zdaniem Ronalda Havenaara sukces ten można przypisać względnemu umiarkowaniu ugrupowania w owym czasie, zwłaszcza na tle wprost nazistowskiej NSNAP, która w tych samych wyborach zdobyła zaledwie 3 tysiące głosów. Nie bez znaczenia był także stosunkowo łagodny wizerunek publiczny samego Musserta ${ }^{10}$.

W warunkach politycznego rozdrobnienia holenderskiej sceny politycznej wzrost siły NSB był tym bardziej znaczący i zaalarmował polityków liberalnych i lewicowych. Ruch, dotąd ignorowany, stał się obiektem coraz silniejszych ataków propagandowych, ponadto już wcześniej został objęty zakazem członkostwa dla urzędników państwowych. Uderzyło to w samego Musserta, który musiał zrezygnować z posady w okręgu wodnym. Działania te, w połączeniu z akcesem do NSB polityków bardziej skrajnych, takich jak Meinoud Rost van Tonningen (wcześniej urzędnik kolonialny i pracownik przedstawicielstwa Ligi Narodów w Wiedniu), doprowadziły do umacniania się tendencji radykalnych i wciąż mocniejszego skrętu ugrupowania na prawo. Na gruncie krajowym przejawiało się to coraz silniejszym akcentowaniem wątków antysemickich,

5 Por. R. Havenaar, Anton Mussert, verrader voor het vaderland. Een biografische schets, Den Haag 1984, s. 36.

6 Zob. R. Havenaar, De NSB tussen nationalisme en 'volkse' solidariteit: De vooroorlogse ideologie van de Nationaal-Socialistische Beweging in Nedeland, Den Haag 1983, s. 112-116. Zob. także I. Schöffer, Het nationaal-socialistische beeld van de geschiedenis der Nederlanden, Utrecht 1978, s. 58-59.

${ }^{7}$ Szerzej por. I. Schöffer, op. cit., s. 59-61.

${ }^{8}$ Dane szczegółowe dotyczące wyborów podaję za: http://www.nlverkiezingen.com (dostęp: 2.11.2017).

${ }^{9}$ G.D. Homan, ,Patriotic” traitors: Dutch national socialists in peace and war, „Pro Rege” 1991, nr 4, s. 8.

10 Autor zauważa, że mianem „holenderskiego Mussoliniego” określano wcześniej raczej przywódcę Partii Antyrewolucyjnej - Hendrika Colijna, premiera w latach 1925-1926 i 19331939, który pielęgnował wizerunek „,silnego człowieka Niderlandów”. Zob. R. Havenaar, Anton Mussert..., s. 44-46. 
W odniesieniu zaś do polityki międzynarodowej — między innymi poparciem inwazji Włoch na Etiopię ${ }^{11}$.

Radykalizacja nie przełożyła się jednak na sukces polityczny, a wręcz przeciwnie. Wybory do Drugiej Izby w 1937 roku ujawniły spadek poparcia dla Ruchu: zdobył wprawdzie cztery mandaty, jednak uzyskał jedynie 171 tysięcy głosów (4,2\% elektoratu), co oznaczało utratę ponad 40\% wcześniejszych zwolenników. Wybory lokalne dwa lata później przyniosły dalszy spadek poparcia Ruch zdobył niecałe 150 tysięcy głosów (3,9\% elektoratu). Wraz ze słabnięciem wsparcia społecznego topnieć zaczęła również liczba członków: od szczytowych 52 tysięcy w 1935 roku do 32 tysięcy w roku $1939^{12}$.

Niemiecka inwazja 10 maja 1940 roku zastała Ruch zdezorganizowany i stosunkowo słaby, zarazem stworzyła jednak wyjątkowe możliwości działania politycznego. Bezpośrednio przed atakiem zaalarmowane zbliżającą się agresją władze państwowe podjęły decyzję o internowaniu pewnej liczby członków NSB uważanych za niebezpiecznych, zarówno w Niderlandach, jak i w Indiach Wschodnich. Wśród zatrzymanych znalazł się Rost van Tonningen, w gronie tym zabrakło natomiast Musserta, który zaczął się ukrywać, choć - paradoksalnie planów jego zatrzymania akurat nie było ${ }^{13}$. Wbrew tym obawom w trakcie działań wojennych, to jest do 15 maja, na szerszą aktywność członków Ruchu w charakterze „piątej kolumny” nie ma dowodów ${ }^{14}$.

Bezpośrednio po kapitulacji armii oraz ewakuacji rządu i królowej Ruch rozpoczął intensywne działania w celu wypełnienia powstałej próżni politycznej. Środkiem do realizacji tego celu miała być kolaboracja z władzami okupacyjnymi. Mussert usiłował nawiązać kontakt z Niemcami już 16 maja, jednak do rozmów doszło dopiero na początku czerwca dzięki zaangażowaniu Rost van Tonningena, w międzyczasie uwolnionego przez Niemców z internowania w Calais ${ }^{15}$.

Warto zauważyć, że NSB nie był jedyną organizacją deklarującą chęć współpracy z okupantem. Wciąż istniały małe partie skrajnej prawicy, takie jak NSNAP. Ponadto szok wywołany błyskawicznym podbojem kraju oraz upadkiem

11 I. Schöffer, op. cit., s. 65-66; R. te Slaa, E. Klijn, De NSB. Ontstaan en opkomst van de Nationaal Socialistische Beweging 1931-1935, Amsterdam 2009, s. 590; J.L. Foray, An old empire in a new order: The global designs of the Dutch Nazi Party 1931-1942, „European History Quarterly” 43, 2013, nr 1, s. 36; R. Havenaar, Anton Mussert..., s. 52-53; idem, De NSB tussen ..., s. 104-106, $112-113$.

12 G.D. Homan, op. cit., s. 9.

13 I. Schöffer, op. cit., s. 71; J.L. Foray, op. cit., s. 37-38.

14 Udokumentowanym przypadkiem tego rodzaju była między innymi pomoc w zdobyciu mostu na Mozie w Gennep, w Limburgii. Był to jednak incydent odizolowany, ponadto akcję przeprowadzili członkowie utworzonej przez Abwehrę organizacji Sport-en-spel, złożonej głównie z Holendrów mieszkających w Niemczech. Mussert zaprzeczał, jakoby działali oni w porozumieniu z NSB, i nazywał ich zdrajcami. Wątpliwości co do związków tej grupy z NSB nie zostały jednak do końca wyjaśnione. Por. S. van der Zee, Voor Führer, volk en vaderland. De SS in Nederland, Hilversum 2008, s. 72-80. Zob. także I. Schöffer, op. cit., s. 71-72.

15 I. Schöffer, op. cit., s. 74-75. 
postrzeganej jako mocarstwo Francji sprawił, że również politycy głównego nurtu (w tym byli premierzy Colijn i de Geer) zaczęli wzywać do pogodzenia się z faktami i akceptacji rzeczywistości, w której dominacja Niemiec będzie głównym czynnikiem kształtującym stosunki społeczno-polityczne w kraju. Zgodnie z tym podejściem powołana w lipcu 1940 roku Unia Niderlandzka (NU) stawiała sobie za cel zabezpieczenie rozwoju społeczeństwa we współpracy z Niemcami, jej celem pośrednim zaś było ograniczanie politycznych wpływów NSB. Unia cieszyła się szerokim poparciem społecznym, w szczytowym okresie liczba jej członków sięgnęła 600 tysięcy osób. Niemcy początkowo tolerowali ten względny pluralizm aktywności politycznej (choć ograniczony zasadniczo do prawicy), jednak ich nastawienie uległo zmianie w 1941 roku, już po agresji na ZSRR. Do końca roku wszystkie organizacje polityczne poza NSB zostały rozwiązane ${ }^{16}$. Ruch okazał się najbardziej obiecującym narzędziem z punktu widzenia użyteczności dla władz okupacyjnych. Dzięki napływowi oportunistów jego liczba członków ponownie wzrosła, osiągając w 1943 roku rekordowe 100 tysięcy ${ }^{17}$. NSB stanowił rezerwuar pomocników, których można było użyć w administracji (zwłaszcza lokalnej) oraz w formacjach paramilitarnych.

Mimo uzyskania pozornie monopolistycznej pozycji na scenie politycznej realny wpływ Ruchu na rzeczywistość pozostał ograniczony. Mussert dążył do powierzenia mu stanowiska premiera, analogicznego do pozycji Vidkuna Quislinga w okupowanej Norwegii. Tymczasem przysięga wierności, którą złożył Hitlerowi jako „germańskiemu wodzowi” w grudniu 1941 roku, oraz uznanie przywódcy NSB przez Hitlera za „przywódcę narodu niderlandzkiego" (Leider van het $\mathrm{Ne}$ derlandsche Volk) w grudniu 1942 roku nie przełożyły się na faktyczną władzę, która nadal spoczywała w rękach komisarza Rzeszy — Arthura Seyss-Inquarta. Jedynym realnym wzmocnieniem pozycji Musserta i NSB było pozwolenie mu na początku 1943 roku na powołanie sekretariatu stanu i mianowanie własnych ,pełnomocników" zaangażowanych w zarządzanie krajem. Mimo kuszenia Niemców perspektywą wprowadzenia poboru wojskowego w Niderlandach, gdyby został mianowany premierem, władze okupacyjne nie spełniły jego życzeń ${ }^{18}$, być może wątpiąc w lojalność przymusowo powołanych holenderskich żołnierzy.

Co więcej, mimo likwidacji innych ugrupowań politycznych wyjątkowa pozycja Ruchu zaczęła być kwestionowana. W przeciwieństwie do Belgii i północnej Francji, pozostających pod wojskowym zarządem Wehrmachtu, okupowane Niderlandy znalazły się pod administracją cywilną, na której czele stał wspomniany komisarz Rzeszy. Sytuacja ta stworzyła szczególnie dogodne warunki do wzrostu wpływów innych niemieckich ośrodków władzy, szczególnie SS,

\footnotetext{
16 Ibidem, s. 84-85.

17 G.D. Homan, op. cit., s. 9-10. Zob. także J.L. Foray, op. cit., s. 40.

18 I. Schöffer, op. cit., s. 87-88; R. Havenaar, Anton Mussert..., s. 88.
} 
reprezentowanego na miejscu przez Hannsa Rautera ${ }^{19}$. Z racji dobrych kontaktów z Himmlerem rzecznikiem interesów tej organizacji w Niderlandach stał się Rost van Tonningen, który dzięki wsparciu Niemców został we wrześniu 1940 roku mianowany drugim (po starym towarzyszu Musserta - Keesie van Geelkerkenie) wiceprzewodniczącym NSB. Mussertowi udało się w końcu zneutralizować pozycję Rost van Tonningena, który został prezesem banku centralnego, jednak rolę reprezentanta Himmlera i „konia trojańskiego SS w NSB” przejął Henk Feldmeijer, równie niebezpieczny przeciwnik ${ }^{20}$. Na początku 1943 roku pojawiały się nawet pogłoski, że to Feldmeijerowi zostanie powierzone zadanie stworzenia rządu (bez Musserta). Jednocześnie kierowane przez niego pismo „Storm” zaatakowało NSB, zarzucając partii propagowanie „myśli antyniemieckiej”21. Mussert oskarżał natomiast SS i Feldmeijera, że stanowią centrum agitacji przeciwko Ruchowi ${ }^{22}$. Otwarty konflikt został stłumiony przez Niemców, którzy obawiając się skutków jego eskalacji, zmusili obydwu adwersarzy do publicznej deklaracji współpracy i jedności.

Oprócz prób podważania pozycji Musserta SS podjęło również konkretne działania mające na celu zwiększenie wpływów w okupowanych Niderlandach. Jeszcze w czerwcu 1940 roku na rozkaz Hitlera utworzono złożony z holenderskich i flamandzkich ochotników pułk SS Westland pod dowództwem Feldmeijera, który później wszedł w skład dywizji Wiking. Ochotnicy byli członkami odrębnego Niderlandzkiego SS (Nederlandsche SS), od listopada 1942 roku nazywanego Germańskim SS w Niderlandach (Germaansche SS in Nederland). Mussert początkowo zabronił członkom NSB wstępowania do tej jednostki, jednak pod presją Niemców zmienił zdanie ${ }^{23}$.

Nieco inny charakter miał Legion Ochotniczy (Vrijwilligerslegioen Nederland), powołany w lipcu 1941 roku i będący elementem szerszego zaciągu europejskich ochotników walczących pod narodowymi znakami przeciwko ZSRR ${ }^{24}$. Mussert był zwolennikiem tej formacji, widząc w niej przeciwwagę dla Niderlandzkiego/Germańskiego SS oraz zalążek przyszłej niderlandzkiej autonomicznej siły zbrojnej ${ }^{25}$. Trzeba jednak zauważyć, że łącznie formacje SS w ponad

19 P. Longerich, Himmler. Buchalter śmierci, przeł. S. Szymański, J. Skowroński, Warszawa 2014, s. 608-610, 707. Zob. także I. Schöffer, op. cit., s. 79-82.

20 R. Havenaar, Anton Mussert..., s. 98-99.

21 Por. I. Schöffer, op. cit., s. 89.

22 Zob. projekt III noty Musserta do Hitlera z 17 maja 1943 roku, [w:] Rijksinstituut voor Oorlogsdocumentatie, Vijf nota's van Mussert aan Hitler over de samenwerking van Duitschland en Nederland in een bond van Germaansche volkeren 1940-1944, Den Haag 1947, s. 69-70.

23 I. Schöffer, op. cit., s. 75-76. Zob. także II notę Musserta do Hitlera z 4 lipca 1941 roku,

[w:] Rijksinstituut voor Oorlogsdocumentatie, op. cit., s. 52.

24 P. Longerich, op. cit., s. 735-738.

25 I. Schöffer, op. cit., s. 84-85; R. Havenaar, Anton Mussert..., s. 86-87. 
połowie składały się z członków NSB ${ }^{26}$, a sam Ruch został w znacznym stopniu wydrenowany zaciągiem prowadzonym przez Feldmeijera i Himmlera.

Niekorzystny dla Niemiec przebieg działań wojennych oraz zaangażowanie NSB — zwłaszcza Oddziałów Ochronnych (Weerbaarheidsafdeling, WA), stanowiących odpowiednik niemieckich Oddziałów Szturmowych (Sturmabteilung, SA) - w działania antyżydowskie i skierowane przeciwko ruchowi oporu zaowocowały rosnącą i coraz bardziej otwartą nienawiścią ze strony ludności. Pogłoski o opanowaniu przez aliantów Bredy i rychłym — jak sądzono — wyzwoleniu reszty Niderlandów doprowadziły 5 września 1944 roku (tak zwany szalony wtorek - dolle dinsdag) do wybuchu entuzjazmu wśród ludności kraju, a jednocześnie do paniki wśród Niemców i kolaborantów. W następstwie tych wydarzeń około 65 tysięcy członków i sympatyków NSB uciekło do Niemiec ${ }^{27}$. Choć część później wróciła, a okupacja miała potrwać jeszcze osiem miesięcy, faktycznie Ruch stracił znaczenie polityczne, mimo istnienia struktur aż do wyzwolenia w maju 1945 roku.

Podsumowując historię organizacji, można wyróżnić kilka etapów jej istnienia. NSB dwukrotnie osiągnął szczyt swego znaczenia politycznego: po raz pierwszy na fali sukcesów wyborczych w połowie lat trzydziestych, po raz drugi dzięki zajęciu pozycji jedynego dozwolonego ugrupowania politycznego w okupowanych Niderlandach około 1942 roku. Trzeba jednocześnie pamiętać, że obydwa sukcesy były względne. Najlepszy wynik wyborczy Ruchu nie przekroczył $8 \%$ poparcia elektoratu, $\mathrm{w}$ okresie zaś okupacji ugrupowanie pozostawało przede wszystkim narzędziem służącym interesom władz niemieckich. Przedstawioną dalej analizę koncepcji polityki zagranicznej należy widzieć w tym kontekście.

\section{Wizja rzeczywistości międzynarodowej}

Podobnie jak inne ówczesne ugrupowania wywodzące się ze skrajnej prawicy NSB postrzegał rzeczywistość międzynarodową jako arenę bezwzględnej walki o przetrwanie. Zgodnie z tą wizją tylko narody, które okażą się wystarczająco silne, mogą utrzymać swą niezależność polityczną. To quasi-biologiczne podejście, bliskie zbrutalizowanej wersji realizmu klasycznego, oznaczało, że wzmacnianie potencjału państwa przez rozbudowę sił zbrojnych do odpowiednich (to jest większych niż rywale) rozmiarów było podstawowym środkiem zabezpieczenia żywotnych interesów kraju. W tym kontekście zwolenników rozbrojenia należało traktować jak zdrajców, którzy wystawiali własną ojczyznę na łaskę i niełaskę innych, potężniejszych państw ${ }^{28}$.

26 G.D. Homan, op. cit., s. 10.

27 Ibidem; J. Balicki, M. Bogucka, op. cit., s. 406.

28 R. te Slaa, E. Klijn, op. cit., s. 129-130. Z tego zresztą względu armia powinna być złożona z ludzi reprezentujących odpowiedni światopogląd. Osoby o światopoglądzie „,antymilitary- 
Kraje słabe, padające ofiarą ekspansjonizmu, były w gruncie rzeczy same sobie winne, gdyż przez niezdolność do samoobrony wykazywały swe nieprzystosowanie do rzeczywistości. Państwa silne zaś zdobywały swoją pozycję dzięki potędze, udowadniając tym samym, że zasługują na wyjątkową pozycję na arenie międzynarodowej. Zgodnie z tą logiką nie doszłoby do podboju Mandżurii przez Japonię, gdyby Chiny były wystarczająco silne, by obronić swą integralność terytorialną ${ }^{29}$. W ten sam sposób usprawiedliwiano następnie włoską inwazję na Etiopię i zbrojny podbój tego państwa ${ }^{30}$.

Z punktu widzenia NSB trudno było zmienić ten „,naturalny” porządek rzeczy, a dążenie do zapewnienia bezpieczeństwa zbiorowego $\mathrm{w}$ ramach systemu Ligi Narodów stanowiło jedynie groźną iluzję. Sama Liga była przedmiotem zaciekłej krytyki. Postrzegano ją przede wszystkim jako narzędzie służące utrwaleniu uprzywilejowanej pozycji zwycięskich po I wojnie światowej mocarstw, zwłaszcza Francji ${ }^{31}$. Z tego względu stanowczy sprzeciw Ruchu budziło wysłanie holenderskich żołnierzy w misji obserwacyjnej Ligi do Saary w 1934 roku. Wskazywano, że partycypacja w operacjach organizacji oznacza w istocie zaprzepaszczenie polityki neutralności i działanie wrogie w stosunku do Niemiec ${ }^{32}$. $\mathrm{Z}$ tego samego powodu podkreślano konieczność pokierowania niderlandzkimi zbrojeniami z myślą o wzmocnieniu raczej obrony Indii Wschodnich niż Niderlandów w Europie 33 .

Co więcej, zdaniem Ruchu oprócz funkcjonowania w charakterze promotora interesów francuskich Liga była nieskuteczna oraz niebezpieczna w tym sensie, że utrwalając podziały w Europie powersalskiej, działała na jej niekorzyść na arenie globalnej. Z punktu widzenia Musserta te same mechanizmy walki o przetrwanie występujące między państwami działały również w szerszej skali — na poziomie „cywilizacyjnym”. Rozpad systemu Ligi Narodów przyjęto zatem z ulgą, gdyż oznaczał zniknięcie czynnika osłabiającego Europę jako całość ${ }^{34}$.

NSB konsekwentnie prezentował wizję świata podzielonego na cztery bloki geopolityczne: Europę, Daleki Wschód, Rosję i Amerykę. W myśl tej narracji dominująca dotąd Europa była, ze względu na wspomniane procesy dezintegrujące,

stycznym” lub „nienarodowym” powinny zostać usunięte z sił zbrojnych, podobnie jak żołnierze pozostający ,pod wpływem takich osób”. W praktyce postulat ten miał doprowadzić do usunięcia z wojska komunistów i socjaldemokratów. Por. raport dotyczący werbunku żołnierzy z 14 kwietnia 1934 roku, s. 7-8, Archiwum Niderlandzkiego Instytutu Badań nad Wojną, Holokaustem i Ludobójstwem (dalej: NIOD) w Amsterdamie 123/4.

29 20-punktowy Program NSB z objaśnieniem, s. 14-15, NIOD 123/1.

30 I. Schöffer, op. cit., s. 65.

31 20-punktowy Program NSB..., s. 13.

32 R. te Slaa, E. Klijn, op. cit., s. 485-487.

33 J. Meyers, Mussert. Een politiek leven, Amsterdam 1984, s. 117.

34 Zob. Neerlands toekomst, broszura z przemówieniami Musserta z 1940 roku, s. 25, NIOD 285/32. Zob. także Over den Nederlandschen Staat in het nieuwe Europa, przemówienie Musserta z 31 lipca 1942 roku, s. 3, NIOD 123/167. 
coraz bardziej narażona na niebezpieczeństwo ze strony pozostałych bloków. Przez większość historii Ruchu za źródło głównego zagrożenia uważano Daleki Wschód pod przywództwem Japonii. Aż do 1940 roku obawiano się przede wszystkim japońskiej ekspansji na południe, w kierunku „białych bastionów” Australii i Holenderskich Indii Wschodnich ${ }^{35}$. Co ciekawe, wraz z faktycznym podbojem Indii Wschodnich przez Japończyków na początku 1942 roku główny nacisk zaczęto kłaść na zagrożenie ze strony dwóch pozostałych bloków - bolszewickiej Rosji i kapitalistycznej Ameryki, obydwu jakoby kierowanych przez Żydów ${ }^{36}$. W tej zmianie akcentów można dostrzec logikę polityczną: $\mathrm{z}$ chwilą gdy Japonia stała się sojusznikiem Niemiec, a zagrożenie z jej strony zdążyło się już wcześniej zmaterializować, hasło obrony przed nią przestało być użytecznym narzędziem mobilizacji poparcia. Jednocześnie wojna toczona przez Niemcy przeciwko ZSRR i USA wymagała usprawiedliwienia ideologicznego. Nie znaczyło to jednak, że obawa przed dalekowschodnim ekspansjonizmem całkowicie zniknęła - koncepcja ,trzech wrogów Europy” była przywoływana przez Musserta jeszcze pod koniec 1944 roku $^{37}$.

W tym tytanicznym starciu wielkich geopolitycznych bloków, które NSB widziało najpierw jako majaczące na horyzoncie niebezpieczeństwo, a następnie jako rzeczywistość, głównym zadaniem Europy powinno być utrzymanie własnego stanu posiadania. Przede wszystkim oznaczało to obronę wspomnianych „,redut” na południowym Pacyfiku, a poza tym efektywną kolonizację Afryki i uznanie jej za wyłączną europejską strefę wpływów. Mussert postulował w tym celu ogłoszenie odpowiednika „doktryny Monroe” dla Afryki, zakładającego aktywne zwalczanie jakiejkolwiek ingerencji ze strony państw pozaeuropejskich w sprawy tego kontynentu ${ }^{38}$. W tym kontekście prezentowana przez NSB wizja rzeczywistości międzynarodowej różniła się od koncepcji niemieckiej. W przeciwieństwie do tej drugiej, akcentującej potrzebę podboju i zdobywania nowej przestrzeni życiowej, koncepcja niderlandzka była znacznie bardziej defensywna. Kładła większy nacisk na zagrożenie i wynikającą z niego potrzebę utrwalenia aktualnego stanu posiadania, choć — jak zauważa Jennifer L. Foray — nie była całkowicie pozbawiona elementu ekspansji ${ }^{39}$.

Najpewniejszym sposobem realizacji tego zadania było wzmocnienie europejskiej jedności. Oprócz potrzeby odrzucenia systemu wersalskiego, konserwującego

35 Przemówienie Rost van Tonningena z 24 listopada 1938 roku, s. 11, NIOD 169/698. Zob. także I notę Musserta do Hitlera z 27 sierpnia 1940 roku, [w:] Rijksinstituut voor Oorlogsdocumentatie, op. cit., s. 16-17. Por. Neerlands toekomst, s. 20-21.

36 20-punktowy Program NSB..., s. 5; przemówienie Musserta z 13 grudnia 1942 roku, NIOD $123 / 393$.

37 Por. V notę Musserta do Hitlera z 17 listopada 1944 roku, [w:] Rijksinstituut voor Oorlogsdocumentatie, op. cit., s. 99.

38 Por. Neerlands toekomst, s. 15-16; J.L. Foray, op. cit., s. 32. Zob. także I notę Musserta do Hitlera z 27 sierpnia 1940 roku, s. 16-17.

39 J.L. Foray, op. cit., s. 29, 31. 
nierównoprawną pozycję Niemiec, konieczne było w tym celu osiągnięcie jedności ideologicznej przez przejęcie władzy przez ugrupowania faszystowskie w kolejnych krajach. W lutym 1934 roku Mussert stwierdził, że Włochy, Austria, Węgry, Polska (sic!) i Niemcy są już faszystowskie, Europa Zachodnia zaś pójdzie w ich ślady ${ }^{40}$. Zgodnie $\mathrm{z}$ tym podejściem połączone wspólną ideologią rządy państw europejskich miały się lepiej rozumieć i zdołałyby stworzyć wspólny front wobec zagrożeń zewnętrznych. Jednocześnie dzięki wspólnemu wysiłkowi kraje te mogłyby, przez odstraszanie, zażegnać niebezpieczeństwo agresji ze strony pozostałych bloków. Alternatywą dla takiej przyszłości było utrzymanie istniejącego systemu, co z racji jego immanentnych napięć doprowadziłoby do wewnątrzeuropejskiej wojny. Ta z kolei byłaby katastrofą, gdyż jeszcze bardziej zmniejszyłaby nadzieje na sukces $\mathrm{w}$ starciu z pozostałymi blokami.

\section{Stosunek do głównych mocarstw europejskich}

Zasygnalizowane w poprzednim punkcie dążenie do wzmocnienia jedności europejskiej przekładało się na bardziej szczegółowe postulaty ułożenia stosunków między Niderlandami a ich sąsiadami. W tym kontekście szczególne znaczenie miały relacje z najbliższymi mocarstwami - Niemcami, Wielką Brytanią i Francją. Zwłaszcza stosunki z Niemcami były tu traktowane priorytetowo. Co prawda w początkach lat trzydziestych NSB nie odrzucał historycznej polityki neutralności, podkreślając, że musi być ona poparta realną siłą, aby agresor czy to Francja, czy Niemcy — wiedział, że kraj będzie się bronił przed inwazją ze wszystkich si ${ }^{41}$. Ponadto $\mathrm{w}$ pierwszej połowie dekady publicznie podkreślano raczej ideologiczną bliskość z włoskim faszyzmem niż z nazizmem ${ }^{42}$. Jednak po 1935 roku nastąpiło wyraźne zbliżenie polityczne Ruchu z Niemcami, dodatkowo wzmocnione obiektywnymi powodami gospodarczymi, to znaczy silnymi niderlandzko-niemieckimi powiązaniami ekonomicznymi. Z natury rzeczy wraz z początkiem okupacji priorytet ten stał się jeszcze bardziej oczywisty.

W optyce Ruchu Niemcy przedstawiały się jako najsilniejsze państwo europejskie oraz naturalny lider kontynentu, a przynajmniej jego północnej części. Jednocześnie widziano je jako kraj niesprawiedliwie potraktowany przez zwycięskie mocarstwa zachodnie. $Z$ tego względu kolejne agresywne posunięcia Niemiec NSB przyjmował z mieszaniną zrozumienia i podziwu. Odrzucenie wersalskich limitów zbrojeniowych oraz remilitaryzację Nadrenii interpretowano jako przywrócenie właściwej zasady, zgodnie z którą każdy naród ma pełne prawo do wyłącznego decydowania o swoich sprawach $^{43}$. Agresywne zamiary wobec

\footnotetext{
40 R. te Slaa, E. Klijn, op. cit., s. 483-485.

41 A. Mussert, Mussert spreekt, przemówienie z 21 września 1934 roku, Utrecht 1934, s. 8.

42 R. te Slaa, E. Klijn, op. cit., s. 487-489.

43 J. Meyers, op. cit., s. 116.
} 
Austrii usprawiedliwiano chęcią zgromadzenia wszystkich Niemców w jednym państwie, dodatkowo podkreślając brak rzeczywistego poparcia dla dyktatury Dollfussa i Schuschnigga $\mathrm{w}$ społeczeństwie ${ }^{44}$. Jednoznacznie proniemieckich sympatii Ruchu dowodzi w tym kontekście bagatelizowanie zaangażowania austriackich nazistów w zabójstwo Dollfussa (z podkreślaniem, że gdyby Niemcy rzeczywiście wspierały pucz, bez wątpienia odniósłby on sukces). Ignorowano ponadto istotny rozdźwięk między Niemcami a Włochami co do przyszłości Austrii $^{45}$. Na zasadzie unifikacji etnicznej popierano również przyłączenie Kraju Sudeckiego do Rzeszy we wrześniu 1938 roku. Większej elastyczności wymagało natomiast wytłumaczenie kolejnych posunięć Hitlera. Rozbicie Czechosłowacji w marcu 1939 roku interpretowano jako „samoobronę" ze strony Niemiec oraz skutek manipulacji radzieckich. Podobnie atak na Polskę thumaczono machinacjami władz brytyjskich, które miały zmusić polski rząd do nieprzyjęcia ,umiarkowanych" żądań niemieckich ${ }^{46}$.

Jak zauważał Ronald Havenaar, marzec 1939 roku był istotnym punktem krytycznym w historii koncepcji zagranicznych NSB. Wkroczenia do Pragi nie sposób było już traktować jako naprawienia rzekomych niesprawiedliwości traktatu wersalskiego. Mimo to z powodów politycznych zdecydowano się na publiczne popieranie stanowiska niemieckiego, choć prywatnie Mussert nazywał działania Rzeszy agresją ${ }^{47}$. Z tych samych względów uderzenie na Polskę uznawał za usprawiedliwioną konieczność korekty granicznej. Podkreślał jednak prawo „dwudziestomilionowego narodu polskiego" do niezależności i pełnoprawnego udziału w rodzinie narodów europejskich, przewidując jednocześnie ograniczenie

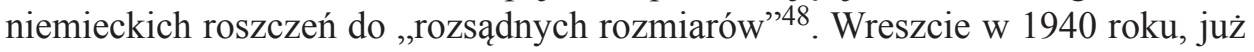
w trakcie okupacji, usprawiedliwił niemiecką inwazję na Niderlandy względami praktycznymi (strategiczne położenie kraju) oraz niewiarygodnością ówczesnego holenderskiego rządu. Zadeklarował również, że gdyby trzy lata wcześniej NSB wygrał wybory, Niderlandy przystąpiłyby do wojny po stronie Niemiec ${ }^{49}$, co było równoznaczne z porzuceniem deklarowanego dotąd przywiązania do polityki neutralności.

Niepodległość państw narodowych oraz podkreślanie odrębności narodu niderlandzkiego stanowily punkt wyjścia, gdy chodzi o stosunek do niemieckiego przywództwa czy to przed wojną, czy zwłaszcza po jej wybuchu. Wobec niebezpieczeństwa, że Niderlandy ostatecznie podzielą los Austrii i zostaną po prostu wcielone do Niemiec, Mussert był przekonany, że kraj może uniknąć tego losu jedynie dzięki

\footnotetext{
44 Raport Samuela van Lunterena z 1938 roku, NIOD 123/81.

45 R. te Slaa, E. Klijn, op. cit., s. 495, 534.

46 I. Schöffer, op. cit., s. 71; J. Meyers, op. cit., s. 117-118.

47 R. Havenaar, De NSB tussen..., s. 150-151.

48 A. Mussert, Waar het om gaat. Danzig en de Corridor, „Volk en Vaderland” 1.09.1939.

49 Neerlands toekomst, s. 8-9.
} 
jego przywództwu oraz lojalnej współpracy z okupantem ${ }^{50}$. Polityczną koncepcją umożliwiającą zachowanie niezależności przy jednoczesnym uznaniu czołowej roli Niemiec w Europie był projekt Związku Państw Germańskich (Germaansche Statenbond), nakreślony przez Musserta w sierpniu 1940 roku.

Związek miał być formą kooperacji sześciu narodów — Niemców, Holendrów, Norwegów, Duńczyków, Szwedów i Szwajcarów - opartą na wspólnocie rasowej i światopoglądowej, wspólnych siłach zbrojnych oraz wspólnocie gospodarczej $^{51}$. Pierwszy element oznaczał zastosowanie kryterium etnicznego i wykluczał ze Związku zarówno Słowian, jak i „niegermańskiego” pochodzenia Belgów czy Szwajcarów. Wspólnota ideologiczna oznaczała rządy narodowosocjalistyczne, zasadzające się na systemie jednopartyjnym i modelowane na wzór niemiecki, choć z uwzględnieniem lokalnych uwarunkowań. Siły zbrojne miały być zintegrowane pod niemieckim dowództwem powyżej poziomu pułku. Pułki powinny natomiast składać się z żołnierzy jednej narodowości i walczyć pod własnymi narodowymi znakami i komendami w języku narodowym ${ }^{52}$. Kooperacja ekonomiczna miała z kolei opierać się na specjalizacji poszczególnych części składowych Związku. Mieszkańcy Niderlandów mieli w tym kontekście zająć się głównie rolnictwem, rybołówstwem i handlem, czyli tradycyjnymi w historii kraju obszarami działalności gospodarczej. Przede wszystkim mieli jednak stanowić forpocztę wysiłków kolonizacyjnych podejmowanych w imieniu Związku. Trzeba zauważyć, że plany dotyczące współpracy ekonomicznej nakreślono stosunkowo ogólnie i nie poświęcono im tyle uwagi co trzem pierwszym punktom. Mimo to Mussert często podkreślał szerokie perspektywy gospodarki Niderlandów wynikające z zacieśnionej współpracy z Niemcami ${ }^{53}$.

Celem istnienia Związku miała być przede wszystkim wspólna obrona oraz skuteczna realizacja interesów składających się na niego narodów. Zadaniem dalekosiężnym miała być natomiast wspólna ze Wspólnotą Łacińską (pod przywództwem Włoch) ,przebudowa światowego porządku zgodnie z ideami narodowego socjalizmu" ${ }^{\text {54 }}$. Poszczególne państwa wchodzące w skład Związku miały zachować niezależność w takim zakresie, w jakim nie przeszkadzałoby to w realizacji celów określonych przez Führera Niemiec. Byłby on naczelnym dowódcą wspólnych sił zbrojnych oraz określałby politykę zagraniczną Związku. Całkowicie pod kontrolą

50 R. Havenaar, Anton Mussert..., s. 74, 82.

51 Projekt w I nocie Musserta do Hitlera z 27 sierpnia 1940 roku, s. 19-30.

52 W II nocie do Hitlera z 4 lipca 1941 roku Mussert nieco zmodyfikował ten plan, wskazując, że niektóre rodzaje wojska (na przykład lotnictwo) mogłyby zostać całkowicie zintegrowane. Wojska lądowe powinny natomiast zachować narodowy charakter na poziomie mniejszych jednostek. Por. Rijksinstituut voor Oorlogsdocumentatie, op. cit., s. 51.

53 Neerlands toekomst, s. 27-28; Over den Nederlandschen Staat..., s. 12-14.

54 Przemówienie Willema Kostera z lutego 1941 roku, s. 6, NIOD 123/133. 
krajów członkowskich pozostałyby z kolei takie kwestie, jak oświata, polityka kulturalna czy aparat urzędniczy ${ }^{55}$.

Co istotne, w rękach narodowych miała również pozostać policja ${ }^{56}$. Podporządkowanie sił porządkowych bezpośrednio Berlinowi, do czego dążył Himmler, oznaczałoby bowiem sprowadzenie państw członkowskich Związku do roli marionetek. To natomiast, podobnie jak hasła wzywające do wcielenia Niderlandów do Rzeszy, stanowiło zdaniem Musserta sabotaż wspólnego wysiłku wojennego i było wodą na młyn propagandy anglo-amerykańskiej ${ }^{57}$. Opinie te były jednoznacznie skierowane przeciwko związanej z SS frakcji wewnątrz Ruchu, odrzucającej koncepcję Związku i wzywającej do stworzenia Rzeszy Wielkogermańskiej, która miałaby powstać przez inkorporację państw germańskich. Co ciekawe, głoszący je Rost van Tonningen nie zakładał wcale podporządkowanego statusu narodu niderlandzkiego, lecz w prywatnych rozmowach wskazywał, że „w ciągu jednego pokolenia Holendrzy zaczną rządzić Rzeszą”. Podobnie uważali Feldmeijer i jego zwolennicy ${ }^{58}$. Przywódca NSB zdecydowanie odrzucał inkorporację. Podkreślając odrębność etniczną własnego narodu, Mussert w czerwcu 1943 roku stwierdził nawet, że nikt nie pytał Holendrów, czy chcą zostać Niemcami, podobnie jak on nie będzie prosił Niemców, by stali się Holendrami ${ }^{59}$.

Stworzenie Związku Państw Germańskich pozostało do końca wojny preferowaną przez Musserta koncepcją ułożenia stosunków w Europie. Zgłoszony przez niego jeszcze w grudniu 1944 roku projekt utworzenia ,jądra europejskiego" był w istocie nieznacznie zmodyfikowaną jego wersją ${ }^{60}$. Warto w tym miejscu zauważyć, że koncepcja Związku w praktyce nigdy nie była traktowana przez Niemców poważnie. Choć przyszły status Niderlandów nie został przez nich jasno określony w okresie okupacji, było raczej oczywiste, że nie przewidywano dla nich żadnej formy niezależności. Projekty inkorporacyjne były w zasadzie popierane przez wszystkie niemieckie ośrodki władzy, nie tylko przez SS, choć ze względów taktyczno-propagandowych wstrzymywano się z ich ogłoszeniem przed końcem wojny ${ }^{61}$.

Dwa pozostałe mocarstwa zachodnioeuropejskie zajmowały w narracji politycznej Ruchu znacznie mniej miejsca niż Niemcy. Jeśli chodzi o Francję, była ona przedstawiana jako zagrożenie i mocarstwo ekspansywne. Walki z „latynizacją”, rozumianą jako rozszerzanie się kulturowej strefy wpływów francuskich

55 Over den Nederlandschen Staat..., s. 11, NIOD 123/167. Zob. także przemówienie sekretarza generalnego Carolusa Huygena z 21 lutego 1942 roku, NIOD 123/393.

56 II nota Musserta do Hitlera z 4 lipca 1941 roku, s. 54-55.

57 Over den Nederlandschen Staat..., s. 5-10. Zob. także dyskusję na temat przemówienia Rost van Tonningena z 8 lutego 1941 roku, NIOD 123/133.

58 I. Schöffer, op. cit., s. 82; S. van der Zee, op. cit., s. 111-112.

59 Opinia ta, choć wygłoszona publicznie, została później ocenzurowana przez Niemców. Zob. I. Schöffer, op. cit., s. 89-90.

60 V nota Musserta do Hitlera z 17 listopada 1944 roku, s. 103-104.

61 R. Havenaar, Anton Mussert..., s. 82. 
kosztem kultury germańskiej, doszukiwano się już w czasach średniowiecznych (tak zwana bitwa złotych ostróg z 1302 roku) oraz w reformacji ${ }^{62}$. Francję utożsamiano również z głównym beneficjentem niesprawiedliwego systemu Ligi Narodów. Francuskiej agresywności nie widziano przy tym wyłącznie jako fenomenu z przeszłości - dostrzegano raczej chęć umocnienia hegemonii Paryża oraz dalszej ekspansji. W tym kontekście roszczenia terytorialne Belgii (uważanej za francuską marionetkę) traktowane były jako wstęp do odepchnięcia Niderlandów z rejonu ujścia Renu oraz przejęcia tamtejszych portów. To zaś w konsekwencji oznaczałoby utratę istotnego źródła dobrobytu kraju ${ }^{63}$.

Pokonanie Francji przez Niemcy w kampanii 1940 roku przyjęto z satysfakcją. Jednocześnie wiązało się to $\mathrm{z}$ usunięciem jej z roli najważniejszego przeciwnika. Francji nie poświęcano odtąd więcej uwagi, choć dopuszczano pewną współpracę z nią, na przykład w ramach wspomnianej już koncepcji jądra europejskiego. $\mathrm{Na}$ miejscu czołowego adwersarza kraj ten zastąpiła Wielka Brytania.

Stosunek NSB do tego państwa był w historii Ruchu niejednoznaczny i cechował się mieszaniną szacunku i niechęci. Niezaprzeczalną potęgę imperium brytyjskiego traktowano jako wiadomy dowód wyższości Europejczyków nad narodami innych kontynentów. Ponadto znaczenie miały germańskie korzenie kulturowe Anglików i ich wspólne z innymi narodami germańskimi pochodzenie. W 1934 roku Mussert spotkał się zresztą z przywódcą Brytyjskiej Unii Faszystów Oswaldem Mosleyem i choć nie nawiązano szerszej współpracy politycznej, był pod wrażeniem swojego rozmówcy ${ }^{64}$. W drugiej połowie lat trzydziestych poglądy te przekładały się na koncepcję, zgodnie z którą zadaniem Niderlandów powinno być odgrywanie roli „budowniczego mostów” między imperium brytyjskim a rosnącymi w potęgę Niemcami ${ }^{65}$. Wizja ta, której ukoronowaniem byłoby powstanie sojuszu niemiecko-brytyjskiego, była w zasadzie zgodna z ówczesnymi dążeniami Hitlera.

Wybuch wojny sprawił, że projekt ten stał się nierealny, a stosunkowo pozytywny obraz Wielkiej Brytanii ustąpił w retoryce Ruchu miejsca niechęci i wrogości. Brytyjczyków oskarżano o prowadzenie antyholenderskiej polityki już od czasów Cromwella oraz o odebranie znacznej części holenderskiego imperium kolonialnego - Nowego Amsterdamu (Nowego Jorku), posiadłości w Gwinei, Cejlonu i Kolonii Przylądkowej ${ }^{66}$. W tym samym świetle przedstawiano podbój

62 Por. R. van Genechten, Dietsche verbondenheid, Leiden 1938, s. 7-9. Zob. także przemówienie Rost van Tonningena z 8 lutego 1941 roku, s. 5, 12.

63 R. te Slaa, E. Klijn, op. cit., s. 485-487.

64 Ibidem, s. 489-490.

65 R. Havenaar, Anton Mussert..., s, 56.

66 I. Schöffer, op. cit., s. 208-209, 231-235. 
republik burskich, podczas gdy dowodem prostej kontynuacji tej zaborczej polityki była zdaniem Musserta okupacja Curaçao przez brytyjskie wojsko w 1940 roku ${ }^{67}$.

Obraz ,perfidnego Albionu” zestawiany był — zwłaszcza na początku wojny — z wizją upadającego imperium, które stoi na krawędzi rozpadu i nie chce pogodzić się z utratą swej hegemonicznej pozycji. Wskutek tego uporu Brytyjczycy woleli doprowadzić do wojny i zaryzykować dominującą pozycję całej Europy, niż oddać przywództwo Niemcom, mimo wspaniałomyślnych prób porozumienia podejmowanych przez tych ostatnich ${ }^{68}$. Ze względu na ich germańskie pochodzenie Mussert dopuszczał w zasadzie członkostwo Brytyjczyków w omówionym Związku Państw Germańskich, uznawał je jednak za mało prawdopodobne — z jednej strony ze względu na ich niechęć do ustąpienia z pozycji hegemona, z drugiej zaś z powodu ich zbyt bliskich związków z USA, które w naturalny sposób dążyły do podważenia uprzywilejowanej roli Europy na świecie, by samemu zacząć ją odgrywać ${ }^{9}$.

Można stwierdzić, że Ruch prezentował stosunkowo konsekwentną wizję pożądanego kształtu systemu europejskiego. Centralna pozycja Niemiec przy zastrzeżeniu względnej niezależności krajów satelickich była stałym punktem, obecnym od czasu wykrystalizowania się koncepcji w połowie lat trzydziestych. Warto również zauważyć, że mimo innego niż większość innych sił politycznych wskazania głównego źródła zagrożenia (Francja) aż do wybuchu wojny Ruch akceptował neutralność jako podstawową zasadę polityki zagranicznej. Zmiana nastąpiła wraz z początkiem okupacji. Także w tym okresie to Wielka Brytania zajęła w narracji NSB miejsce głównego przeciwnika w Europie. Projekt Związku Państw Germańskich, choć pojawił się dopiero po inwazji Niderlandów i przewidywał ściślejszy zakres kontroli Niemiec nad pozostałymi krajami, był w swej istocie kontynuacją wcześniejszych koncepcji, aczkolwiek dostosowaną do nowych warunków.

\section{Koncepcja Wielkich Niderlandów}

Bardzo istotne z punktu widzenia Ruchu były stosunki z Belgią. Oprócz omówionych wcześniej kwestii geopolitycznych — belgijskich roszczeń terytorialnych, kwestii gospodarczych oraz relacji z Francją — szczególne znaczenie przywiązywano do zagadnienia statusu Flamandów. Mówiących po niderlandzku mieszkańców regionu NSB traktował zasadniczo tak samo jak Holendrów

${ }^{67}$ Od 1941 roku w Surinamie stacjonowały natomiast wojska amerykańskie. Por. J.L. Foray, op. cit., s. 41-43.

${ }^{68}$ Neerlands toekomst..., s. 3-4. Zob. także przemówienie Rost van Tonningena z 8 lutego 1941 roku, s. 15-16.

69 Zob. I notę Musserta do Hitlera z 27 sierpnia 1940 roku, s. 19. 
z północy, którzy jednak wskutek nieszczęśliwych wydarzeń historycznych (zainicjowanych przez Francję) znaleźli się poza własnym krajem.

Pogląd o konieczności zjednoczenia Holendrów i Flamandów w jednym kraju, określanym jako „Dietsland”70, nie był bynajmniej ograniczony do członków i sympatyków Ruchu ${ }^{71}$. W gruncie rzeczy wielu badaczy argumentuje, że dla samego Musserta początkowo nie miał on kluczowego znaczenia i służył przede wszystkim jako narzędzie przyciągające do NSB sympatyków i działaczy ze środowisk zainteresowanych tematyką wielkoniderlandzką ${ }^{72}$. Wydaje się jednak, że nawet jeśli z początku w Ruchu traktowano tę kwestię instrumentalnie, to szybko awansowała ona $\mathrm{w}$ hierarchii postulatów. Zresztą już w początkowym programie z 1931 roku znalazł się postulat uregulowania stosunków z ,diasporą mieszkającą poza obrębem Królestwa" ${ }^{73}$ w formie możliwie zbliżonej do stosunków w ramach Królestwa. Było to wprawdzie stwierdzenie dość niejasne, jednak dowodzące faktycznego uznania, że część narodu mieszka poza własnym państwem ${ }^{74}$. Naród definiowano w tym kontekście jako wspólnotę ,rasową”, językową i kulturową $^{75}$. Należy jednak zauważyć, że język programu pozostawał dość wyważony, jeśli chodzi o praktyczne aspekty koncepcji połączenia. Deklarowano wprawdzie sympatię wobec walki Flamandów o równouprawnienie, aczkolwiek nie wysuwano konkretnych propozycji jej wsparcia przez rząd Niderlandów ani nie formułowano wprost dążeń aneksjonistycznych ${ }^{76}$.

Dopiero wybuch wojny, okupacja Niderlandów i Belgii oraz względnie uprzywilejowana pozycja NSB zaowocowały wzrostem nadziei na rzeczywistą realizację postulatów zjednoczeniowych. Biorąc pod uwagę, że Niemcy już w czasie I wojny światowej kusiły Niderlandy perspektywą przyłączenia Flandrii w zamian za przystąpienie do państw centralnych ${ }^{77}$, politycy Ruchu liczyli na podobną ofertę. Dawali jej wyraz, postulując utworzenie zjednoczonego państwa „od Dollart do Calais”, co oznaczało inkorporację Flandrii wraz z Brukselą, a także Flandrii Francuskiej, zamieszkanej przez ludność posługującą się językiem niderlandzkim ${ }^{78}$.

70 Nie ma polskiego odpowiednika. Określenie pochodziło od przymiotnika dietsch lub w mniej archaicznej formie diets, oznaczającego starą nazwę języka niderlandzkiego.

71 L. Wils, op. cit., s. 24-31.

72 Zob. np. I. Schöffer, op. cit., s. 62-63; J. Meyers, op. cit., s. 59; R. Havenaar, De NSB tussen..., s. 116-117.

73 „Delen van de Dietsche stam buiten het Rijksverband” - 20-punktowy Program NSB..., pkt 2.

74 Por. R. te Slaa, E. Klijn, op. cit., s. 131.

75 R. van Genechten, op. cit., s. 9-11. Zob. także R. te Slaa, E. Klijn, op. cit., s. 700-702.

76 20-punktowy Program NSB..., s. 11-12. Zob. także R. van Genechten, op. cit., s. 27-28.

77 B. de Wever, Groot-Nederland als utopie en mythe, „Bijdragen tot de Eigentijdse Geschiedenis" 1998, nr 3, s. 164.

78 I nota Musserta do Hitlera z 27 sierpnia 1940 roku, s. 21-22. Por. przemówienie Willema Kostera z lutego 1941 roku, s. 1. Zob. także Neerlands toekomst..., s. 25-27; I. Schöffer, op. cit., s. 76 . 
Mimo podkreślania analogii między sytuacją Niderlandów a oddzieleniem Austrii od Rzeszy, które „naprawiono” Anschlussem, Niemcy nie wykazali zainteresowania postulatami Ruchu. Po wizycie u Hitlera w grudniu 1941 roku Mussert nabrał pewności, że w przewidywalnej przyszłości nie można liczyć na realizację tego pomysłu. W konsekwencji przestał się on pojawiać w wypowiedziach przedstawicieli NSB tak często jak do tej pory ${ }^{79}$. Nie znaczy to jednak, że całkowicie go porzucono. Mussert liczył bowiem, że Hitler z czasem zmieni zdanie. Szans na realizację idei zjednoczeniowej upatrywano jednak raczej w okresie powojennym $^{80}$. Warto nadmienić, że idea wielkoniderlandzka stała się z czasem przedmiotem ataku ze strony Rost van Tonningena i jego stronników w ramach Ruchu. Podkreślali oni, że tak jak zjednoczone Królestwo Niderlandów z lat 1815-1830 było sztucznym tworem powstałym z inspiracji Brytyjczyków, tak „Dietsland” byłby w istocie wyrazem separatyzmu w odniesieniu do Rzeszy Wielkogermańskiej ${ }^{81}$. Stosunek do połączenia z Flandrią był zatem kolejnym przejawem walki ideologicznej między NSB a SS.

Zjednoczenie Flandrii i Niderlandów stanowiło również istotne zagadnienie polityczne po południowej stronie granicy. Było ono postulowane przez powstały w 1931 roku Związek „Dietslandzkich” Narodowych Solidarystów (Verdinaso) Jorisa van Severena, a następnie także przez powołany w 1933 roku Flamandzki Związek Narodowy (VNV) pod przywództwem Stafa de Clercqa. Wraz z woltą van Severena, który w 1934 roku porzucił projekt wielkoniderlandzki na rzecz koncepcji „burgundzkiej” (wspólnoty Flamandów, Walonów i Luksemburczyków), czołowa rola wśród flamandzkich zwolenników zjednoczenia z Niderlandami przypadła jednoznacznie $\mathrm{VNV}^{82}$. Ugrupowanie to cieszyło się stosunkowo dużym poparciem ${ }^{83}$, a po rozpoczęciu okupacji podjęło kolaborację z Niemcami. Pozycja VNV wobec okupantów była jednak słabsza niż NSB na północy. Było tak częściowo dlatego, że Niemcy, dążąc do pozyskania Walonów, unikali kroków sugerujących chęć rozbicia Belgii. Poza tym, podobnie jak na północy, we Flandrii pojawiła się konkurencja dla VNV w postaci popieranego przez SS Niemiecko-Flamandzkiego Związku Pracy (DeVlag). Formacja ta, pod przewodnictwem Jefa van de Wiele, opowiadała się za inkorporacją kraju do Rzeszy Wielkogermańskiej. W 1944 roku to DeVlag, a nie VNV stał się najważniejszym ugrupowaniem kolaboracyjnym ${ }^{84}$, choć nie miało to już praktycznego znaczenia $\mathrm{z}$ racji opanowania Belgii przez aliantów.

79 R. Havenaar, Anton Mussert..., s. 81.

80 J. Meyers, op. cit., s. 218.

81 List Rost van Tonningena do Musserta z 22 października 1941 roku, NIOD 285/11. Zob. także I. Schöffer, op. cit., s. 92, 217.

82 Szczegółowa historia ruchów zob. B. de Wever, op. cit., s. 164-169.

83 Zob. J. Łaptos, op. cit., s. 221-223.

84 I. Schöffer, op. cit., s. 90-94; B. de Wever, op. cit., s. 172-176. 
NSB nawiązał kontakty z Verdinaso już w 1934 roku, jednak zmiana frontu u van Severena wzbudziła duże rozczarowanie. W 1935 roku Mussert spotkał się z de Clercqiem i od tego czasu to VNV była uważana za główny punkt kontaktowy Ruchu po drugiej stronie granicy ${ }^{85}$. Wydaje się jednak, że współpracę tę traktowano raczej instrumentalnie, a VNV była postrzegana raczej jako użyteczne narzędzie niż równoprawny partner. We Flandrii przez pewien czas funkcjonowały dwa przedstawicielstwa NSB, które sprzeciwiały się próbom unifikacji skrajnej prawicy forsowanym przez de Clercqa, wskazując, że VNV ma zbyt katolicki charakter $^{86}$. Samego de Clercqa oraz jego następcę od października 1942 roku, Hendrika Eliasa, uważano za przywódców tymczasowych, którzy wprawdzie chwilowo mogą poprowadzić Flamandów, jednak nie dłużej niż do momentu, w którym władzę ,za zgodą Führera” obejmie przywódca całych Niderlandów — w domyśle Mussert ${ }^{87}$. Ten ostatni zresztą już w 1940 roku całkiem otwarcie wypowiadał się w imieniu Flamandów, w swej nocie do Hitlera całkowicie ignorując istnienie $\mathrm{VNV}^{88}$.

Oryginalnym wkładem NSB w koncepcję wielkoniderlandzką było podkreślanie, że naród składa się nie tylko z Holendrów i Flamandów, lecz także z Afrykanerów ${ }^{89}$. Podejście to łączyło, z jednej strony, poczucie więzi Holendrów z mieszkańcami Transwalu i Oranii, wzmocnione w okresie wojen burskich, z drugiej zaś - sentyment antybrytyjski, co współgrało z przywołanym wcześniej przedstawianiem Brytyjczyków jako głównego wroga ${ }^{90}$. Przy okazji podkreślanie rozbicia narodu na trzy, a nie dwie części, zmniejszało względną rolę Flandrii w koncepcji zjednoczeniowej ${ }^{91}$.

Już po wybuchu wojny Mussert deklarował życzenie, by po oczekiwanej klęsce Wielkiej Brytanii holenderscy żołnierze wzięli udział w wyzwalaniu Kolonii Przylądkowej i dawnych republik burskich ${ }^{92}$. Można sądzić, że po zdobyciu południowej Afryki przewidywał dla niej rolę integralnego elementu „Dietslandu”, nie zaś zwykłej kolonii. Miała ona stanowić szczególny wyjątek: jedyną część Związku Państw Germańskich położoną poza kontynentem europejskim ${ }^{93}$. Ponadto plany eksploatacji i kolonizacji dotyczyły również belgijskiego Konga. Zdaniem Musserta obszar ten został spenetrowany głównie przez Flamandów,

85 R. van Genechten, op. cit., s. 27-28. Zob. także R. te Slaa, E. Klijn, op. cit., s. 492-493, 703-705.

${ }^{86}$ Korespondencja Pieta van Rossema do Musserta z 1940 roku, NIOD 123/118. Zob. także B. de Wever, op. cit., s. 176.

87 Raporty na użytek NSB z 1941 i 1942 roku, NIOD 123/118.

88 Zob. I notę Musserta do Hitlera z 27 sierpnia 1940 roku, s. 32.

89 R. te Slaa, E. Klijn, op. cit., s. 131.

90 I. Schöffer, op. cit., s. 231-235.

91 Tak sugeruje J.L. Foray, op. cit., s. 32.

92 A. Mussert, Mussert spreekt..., s. 17-18.

93 I nota Musserta do Hitlera z 27 sierpnia 1940 roku, s. 20. 
a nie przez Walonów, zatem w naturalny sposób powinien stać się posiadłością kolonialną ,Dietslandu"94.

Mimo pewnych przedwojennych kontaktów z przedstawicielami NSB prawicowi przywódcy burscy zasadniczo zachowywali dystans wobec głoszonych przez Musserta koncepcji wspólnoty. Stosunkowo najbardziej utożsamiał się z nimi Johannes van Rensburg, późniejszy przywódca Ossewabrandwag - radykalnej organizacji zdelegalizowanej przez władze w 1942 roku. Politycy Partii Narodowej (NP), tacy jak Daniel Malan, choć przywoływali wspólną historię i holenderskie pochodzenie Burów, podkreślali własną odrębność językową i narodową. Paradoksalnie do większej wspólnoty z Niderlandami nawoływał premier Związku Południowej Afryki Jan Smuts, wykorzystujący niemiecką agresję i okupację do mobilizacji własnych zwolenników. Malan, występując z pozycji antywojennych, podkreślał natomiast, że nie ma powodu, by Burowie walczyli za Holandię, skoro Holendrzy nie przyszli z pomocą republikom w czasie wojen burskich ani Belgii w trakcie I wojny światowej ${ }^{95}$.

Nawet jeśli dążenie do zjednoczenia rozproszonej wspólnoty narodowej „Dietslandu” było początkowo wykorzystywane instrumentalnie do doraźnych celów politycznych, okazało się jednak trwałym aspektem koncepcji polityki zagranicznej Ruchu. Siła artykulacji tego postulatu osiągnęła apogeum na początku okupacji, lecz wskutek niechęci okazywanej jej przez Niemców osłabła. Nie zmienia to wszakże faktu, że idea zjednoczenia pozostała obecna w wypowiedziach Musserta aż do końca istnienia NSB.

\section{Imperium kolonialne}

Zainteresowanie sprawami południowej Afryki było tylko jednym z licznych przejawów znaczenia, jakie NSB przywiązywał do problematyki terytoriów zamorskich. Jak sygnalizowano wcześniej, najważniejszego zadania Holendrów w „nowej Europie” upatrywano w działalności kolonizacyjnej. Przeświadczenie o żywotnym znaczeniu kolonii dla Niderlandów występowało jednak przez cały okres istnienia Ruchu, również przed wojną.

Imperium kolonialne spełniało z punktu widzenia NSB kilka funkcji. Po pierwsze, było istotne $\mathrm{z}$ powodów ekonomicznych — jako źródło surowców i rynek zbytu dla Niderlandów. Po drugie, w koloniach widziano przestrzeń do zajęcia przez populację metropolii, wypychaną przez bezrobocie i przeludnienie.

94 Ibidem, s. 22-23. Zob. także J.L. Foray, op. cit., s. 32.

95 P.J. Furlong, Family ties? Afrikaner nationalism, pan-Netherlandic nationalism and neoCalvinist „, Christian nationalism”, „New Contree: A Journal of Historical and Human Sciences for Southern Africa" 2015, nr 74, s. 12-13, 15-19. 
Po trzecie, imperium było w optyce Ruchu źródłem prestiżu i dumy narodowej ${ }^{96}$. Punkty te nie odbiegały zasadniczo od poglądów innych ówczesnych ugrupowań politycznych, wliczając $\mathrm{w}$ to partie głównego nurtu. W odróżnieniu od ugrupowań rządzących NSB podkreślał natomiast, że choć sama idea imperium niderlandzkiego jest skonstruowana poprawnie, to rzeczywiste jego funkcjonowanie pozostawia wiele do życzenia. Przede wszystkim krytykowano niedostateczną obronę przed zagrożeniami zewnętrznymi oraz niefrasobliwe, ,handlowe” podejście do posiadanych terytoriów, na które czyhały inne mocarstwa. Podnoszono również zarzuty zbyt słabej administracji i niewystarczającego zdecydowania w zwalczaniu zagrożeń wewnętrznych (to jest ruchów niepodległościowych). Krytykowano wreszcie brak efektywnego wsparcia przedsięwzięć kolonizacyjnych ${ }^{97}$. Receptami na te problemy miało być znaczne wzmocnienie obrony terytoriów zamorskich oraz przebudowa struktury administracyjnej ${ }^{98}$.

Bez wątpienia najważniejszym z punktu widzenia Ruchu (choć nie tylko jego) terytorium kolonialnym były Holenderskie Indie Wschodnie. Z racji długiej historii powiązań oraz kluczowego znaczenia ekonomicznego były one istotnym czynnikiem kształtującym niderlandzką tożsamość narodową. Ponadto ze względu na rozmiar i liczbę ludności były jedynym czynnikiem pozwalającym Niderlandom pretendować do statusu mocarstwa. Co więcej, dla partykularnych interesów NSB ważne było stosunkowo szerokie poparcie wśród wschodnioindyjskiej administracji kolonialnej, zwłaszcza w latach trzydziestych gotowej do udzielania partii wsparcia materialnego.

Już w 1933 roku powstał oddział Ruchu w Indiach Wschodnich, a wśród jego miejscowych członków znalazła się stosunkowo duża liczba Indoeuropejczyków, to znaczy osób mieszanego niderlandzko-indyjskiego pochodzenia i zazwyczaj mocno zwesternizowanych. Byli oni istotnym elementem władzy, obsadzali stanowiska $\mathrm{w}$ administracji i armii kolonialnej ${ }^{99}$. Jednocześnie stanowili problem, gdyż przez nazistów byli postrzegani jako efekt zmieszania „lepszej” (germańskiej) i „gorszej” (azjatyckiej) krwi ${ }^{100}$. W sumie zarówno w latach trzydziestych, jak i po wybuchu wojny stosunek NSB do Indoeuropejczyków pozostał dwuznaczny. $Z$ jednej strony nie odrzucano zasady rasistowskiej i zapowiadano dążenie do ograniczenia „dalszego mieszania ras”. Z drugiej zaś podkreślano, że „myślący po wielkoniderlandzku” Indoeuropejczycy są kluczowi dla utrzymania władzy w kolonii i nie powinni być wykluczani ze wspólnoty narodowej. Podkre-

96 P.E. Winkler, Blank Nieuw-Guinea. Een nieuw stamland voor het Nederlandsche volk, Utrecht 1935, s. 5, 20, 24.

97 I. Schöffer, op. cit., s. 229-231; J.L. Foray, op. cit., s. 33-34.

98 Szczegóły ujęte w projekcie schematu zarządu posiadłościami, NIOD 123/59.

99 J.L. Foray, op. cit., s. 34-35.

100 Paradoksalnie to właśnie z powodu wątpliwości co do swego pochodzenia Rost van Tonningen nie został początkowo przyjęty do Germańskiego SS w Niderlandach. Udało mu się to dopiero w 1944 roku. Zob. S. van der Zee, op. cit., s. 229-230. 
ślano również, że nawet jeśli są odrzucani przez SS, to powinni móc służyć w WA czy też w formacjach zbrojnych niezwiązanych z organizacją Himmlera ${ }^{101}$.

W odniesieniu do zarządzania Indiami Wschodnimi Ruch odrzucał założenia realizowanej od końca XIX wieku „polityki etycznej”"102, zakładającej w dalekiej perspektywie przekazanie władzy w kolonii miejscowej ludności. Negowano jakiekolwiek koncepcje nadania Indiom Wschodnim stopnia samorządności zbliżonej do statusu brytyjskich dominiów, tym bardziej że z punktu widzenia NSB nie mogło być mowy o żadnej „Indonezji” jako całości, lecz raczej o zbiorze odrębnych terytoriów, które łączyła jedynie zwierzchnia władza Niderlandów. Ruch nie był w tym względzie odosobniony — ten sam pogląd podzielało wielu polityków głównego nurtu, z premierem Colijnem na czele. Był zresztą artykułowany również w okresie powojennym. Zdaniem NSB ludność miejscowa powinna być wdzięczna kolonizatorom, którzy przynieśli jej postęp i dobrobyt, dzięki czemu cieszyli się lepszym życiem niż na przykład mieszkańcy niepodległych Chin. Wobec ruchów niepodległościowych, które podejrzewano o reprezentowanie interesów ZSRR, należało przyjąć twardy kurs i zdusić je w zarodku przy użyciu siły ${ }^{103}$

Szczególnym obszarem wspierania kolonizacji była w koncepcji NSB Nowa Gwinea. Słabo zaludnione i oddzielone pod względem etniczno-kulturowym od reszty kolonii terytorium zdaniem ideologów Ruchu oferowało idealne warunki osadnictwa. Miało ono być zasadniczo ograniczone do białych i Indoeuropejczyków. Miejscowych Papuasów proponowano przesiedlić do rezerwatu, na którego przestrzeń przewidziano jedną trzecią powierzchni wyspy. Dzięki kolonizacji Nowa Gwinea miała stać się bastionem obronnym całych Indii Wschodnich oraz rozwiązaniem kwestii przeludnienia metropolii. Rzeczywiste wysiłki kolonizacyjne, skoncentrowane wokół osady Hollandia (dzisiaj Jayapura), były prowadzone pod egidą Stowarzyszenia na rzecz Kolonizacji Nowej Gwinei (KNG). Mussert je popierał i proponował w latach trzydziestych wysłanie na wyspę 35 tysięcy kolonistów ${ }^{104}$. W praktyce projekty poniosły jednak fiasko i zostały w dużym stopniu zarzucone przed wybuchem wojny. Od tego czasu osadnicze koncepcje Ruchu skoncentrowały się na innych obszarach.

Kluczowym postulatem polityki wobec Indii Wschodnich było natychmiastowe i znaczące wzmocnienie obrony kolonii przed atakiem z zewnątrz. Zdaniem

101 I nota Musserta do Hitlera z 27 sierpnia 1940 roku, s. 24. Zob. także przemówienie Carolusa Huygena z 21 lutego 1942 roku, s. 5-6, NIOD 123/393; IV nota Musserta do Hitlera z 26 października 1943 roku, [w:] Rijksinstituut voor Oorlogsdocumentatie, op. cit., s. 91-92; R. te Slaa, E. Klijn, op. cit., s. 686-687.

102 Więcej o polityce etycznej zob. P. Kołek, Polityka zagraniczna Holandii w latach 19452012, Toruń 2013, s. 276-277.

103 R. te Slaa, E. Klijn, op. cit., s. 677-679; J.L. Foray, op. cit., s. 31, 33-34. Zob. także 20-punktowy Program NSB..., s. 8-9.

104 P.E. Winkler, op. cit., s. 8-11, 30, 54-56. Zob. także H. Meek, Nieuw-Guinea als utopie. Nederlandse kolonisatieplannen 1920-1940, „Tijdschrift voor Geschiedenis” 2009, nr 3, s. 350351, 356-360. 
Musserta, który odwiedził Indie w 1935 roku, zarówno armia kolonialna (KNIL), jak i stacjonująca tam flota prezentowały się żałośnie i nie stanowiły żadnej osłony przed atakiem z zewnątrz. Według niego konieczne było czterokrotne zwiększenie liczebności wojska oraz unowocześnienie marynarki, jeśli miały one odegrać rolę odstraszającą wobec agresywnej Japonii ${ }^{105}$

Po rozpoczęciu okupacji Niderlandów NSB stracił jakikolwiek wpływ na wydarzenia w koloniach, których administracja pozostała wierna rządowi emigracyjnemu. Dotychczasowa narracja uległa wówczas pewnej zmianie. Zagrożenie japońskie zaczęto pomniejszać, dowodząc, że Niemcy nie pozwolą na zajęcie Indii Wschodnich. Po podpisaniu paktu trzech w październiku 1940 roku nadal liczono na utrzymanie kontroli przez metropolię, dopuszczając zarazem jakąś formę koncesji gospodarczych wobec Japonii i obietnicy niedziałania na jej szkodę, na wzór uregulowania sytuacji we francuskich Indochinach ${ }^{106}$.

Gdy do inwazji jednak doszło, Mussert usiłował zdyskontować politycznie tę sytuację, obarczając winą za katastrofę rząd emigracyjny. Argumentował ponadto, że mimo stuleci pokojowych i przyjaznych relacji z Japonią rezydujący w Londynie rząd ochoczo podjął się roli agenta interesów anglo-amerykańskich i sprowokował cesarstwo do ataku. Podkreślał zresztą, że Japonia nie przyjęła wypowiedzenia wojny ze strony Niderlandów oraz że dopiero jednoznacznie wrogie działania wojsk kolonialnych doprowadziły do wybuchu konfliktu. Wskazywał także, że gdyby lata wcześniej poważnie potraktowano jego ostrzeżenia, nie doszłoby do tej sytuacji ${ }^{107}$. Nadziei na odzyskanie Indii Wschodnich do końca wprawdzie nie porzucono, jednak dla NSB było oczywiste, że jeśli kiedykolwiek miałoby to być możliwe, to wyłącznie na drodze negocjacji i dzięki wsparciu Niemiec w ramach Związku Państw Germańskich ${ }^{108}$.

W odróżnieniu od Indii Wschodnich karaibskim posiadłościom Niderlandów poświęcano w NSB znacznie mniej uwagi, co było zresztą typowe dla wszystkich sił politycznych. Oprócz wspomnianych podejrzeń, że Wielka Brytania i USA dążą do przejęcia posiadłości na półkuli zachodniej, i dość rytualnego powtarzania zapewnień o ich równoprawnym statusie w ramach imperium kolonie te właściwie nie zajmowały istotnego miejsca w koncepcjach Ruchu. Jedynym wyjątkiem był pod tym względem wysunięty w 1938 roku autorski plan Musserta dotyczący utworzenia w Gujanie „Żydowskiego Schronienia Narodowego” (Joodsch Nationaal Tehuis).

105 A. Mussert, Mussert spreekt..., s. 8-11. Por. R. te Slaa, E. Klijn, op. cit., s. 690.

106 Por. projekt statutu Związku Państw Germańskich autorstwa Johana Carpa z sierpnia 1940 roku, [w:] Rijksinstituut voor Oorlogsdocumentatie, op. cit., s. 117-118. Zob. także Neerlands toekomst, s. 21-24; J.L. Foray, op. cit., s. 43; J. Meyers, op. cit., s. 217.

107 Por. A. Mussert, Zinloos geofferd. De vernietiging van de Indische kruisers, ,Volk en Vaderland" z 15 lutego 1942 roku. Tezy te powtarza również przemówienie Carolusa Huygena z 21 lutego 1942 roku, NIOD 123/393. Zob. także J.L. Foray, op. cit., s. 43-44.

108 IV nota Musserta do Hitlera z 26 października 1943 roku, s. 117-118. 
Stosunek NSB do Żydów w latach trzydziestych znacznie ewoluował. Początkowo antysemityzm był ograniczony, a partyjna propaganda dystansowała się od prześladowań Żydów w Niemczech. Nie wykluczano ich ze wspólnoty narodowej (pod warunkiem zasymilowania), dopuszczano również ich członkostwo w samym Ruchu (choć nieoficjalną polityką było zamknięcie dla nich stanowisk wyższych niż szeregowe $)^{109}$. Sam Mussert pozostawał wobec Żydów obojętny. Wzmagająca się w drugiej połowie dekady krytyka wobec Ruchu, w połączeniu ze wzrostem jego radykalizacji, zaowocowały jednak zaostrzeniem podejścia antysemickiego. W rezultacie w październiku 1938 roku Żydzi zostali usunięci z partii ${ }^{110}$.

Jednocześnie NSB krytykował przyjmowanie w Niderlandach żydowskich uchodźców z Niemiec oraz żądał wydalenia wszystkich, którzy przybyli do kraju po 1 sierpnia 1914 roku ${ }^{111}$. W celu zlikwidowania napięć na tle antysemickim Mussert zaproponował projekt masowej emigracji Żydów europejskich ${ }^{112}$ oraz wskazał najlepsze miejsce docelowe: Gujanę, podzieloną wówczas pomiędzy trzy państwa kolonialne - Niderlandy, Francję i Wielką Brytanię. Plan zakładał, że terytorium to może pomieścić kilkadziesiąt milionów mieszkańców i potrzebuje osadników i kapitału. Osadnikami mieli być emigranci żydowscy, a niezbędnych środków do budowy infrastruktury miała dostarczyć Ameryka Północna. Koszty przesiedlenia miały natomiast ponieść państwa, które Żydzi opuszczali.

Plan nie ograniczał się jednak do samego przesiedlenia, gdyż ofiarowanie terytorium Gujany na jego potrzeby pociągało za sobą kwestię rekompensat terytorialnych — w każdym razie dla Niderlandów. W zamian za większe terytorium Surinamu Niderlandy miały otrzymać część portugalskiego Mozambiku wraz ze stolicą Lourenço Marques (dzisiaj Maputo). Obszar ten, położony nad zatoką Delagoa, sąsiadował z Transwalem. Propozycja ta korespondowała zatem ze wspomnianym zainteresowaniem południową Afryką. Portugalia miała zostać wynagrodzona analogicznym obszarem belgijskiego Konga. Ludność zamieszkująca Surinam zostałaby natomiast przesiedlona — biali nad zatokę Delagoa, Jawajczycy — do Indii Wschodnich, Indianie zaś i czarni — do rezerwatów ${ }^{113}$.

Aby przedyskutować szczegóły, Mussert zaproponował zorganizowanie międzynarodowej konferencji z udziałem czterech mocarstw — Niemiec, Francji, Wielkiej Brytanii i Włoch, trzech zainteresowanych krajów kolonialnych - Niderlandów, Belgii i Portugalii, oraz państw potencjalnie, jego zdaniem, zainteresowanych emigracją Żydów — Polski, Czechosłowacji, Węgier i Rumunii ${ }^{114}$.

109 I. Schöffer, op. cit., s. 235-237; R. te Slaa, E. Klijn, op. cit., s. 249-251; J. Meyers, op. cit., s. 130; R. Havenaar, op. cit., s. 104.

110 J. Meyers, op. cit., s. 136.

111 A. Mussert, De Verenigde Staten van Guyana. Het Joodsch nationaal tehuis, Leiden 1939, s. 5-6.

112 Ibidem, s. 11-15.

113 J. Meyers, op. cit., s. 138-139, 141.

114 A. Mussert, De Verenigde Staten..., s. 7-8. 
Żadne państwo nie wyraziło ostatecznie zainteresowania planem Musserta, łącznie z Niemcami, w których w owym czasie rozważano raczej koncepcję przesiedlenia Żydów na Madagaskar ${ }^{115}$. Mimo to autor nawiązywał do swego planu jeszcze w sierpniu 1940 roku$^{116}$.

Wobec faktycznego rozerwania po 1940 roku więzi między Niderlandami a terytoriami zamorskimi było oczywiste, że wielkie plany kolonizacyjne Ruchu nie mogą zostać zrealizowane, przynajmniej do czasu zakończenia wojny. Alternatywą dla kolonizacji zamorskiej stało się po inwazji Niemiec na ZSRR osadnictwo na zdobytych terenach wschodnich. W sumie około 6 tysięcy Holendrów wyjechało pod egidą „Niderlandzkiej Kompanii Wschodniej” (NOC), udając się przede wszystkim na obszar Komisariatu Rzeszy Ostland. Projekt zakładał eksploatację ludności miejscowej w charakterze siły roboczej — Rost van Tonningen porównywał Łotyszy i Estończyków do mieszkańców Malajów, zalecając ich surowe traktowanie w celu wymuszenia posłuszeństwa ${ }^{117}$. Kolonizacja wschodu stanowiła zresztą głównie inicjatywę stronnictwa SS w Ruchu. Mussert co prawda publicznie pochwalał projekt, jednak prywatnie wyrażał co do niego wątpliwości i preferował tradycyjny model kolonizacji zamorskiej. Ponadto wolał, żeby dla Holendrów wyznaczono na zdobytym wschodzie wyłączne obszary osadnictwa, co nie odpowiadało „wielkogermańsko” myślącym stronnikom Rost van Tonningena oraz samym Niemcom ${ }^{118}$. Ostatecznie liczni osadnicy wrócili do kraju zniechęceni złymi warunkami, nierównym traktowaniem przez Niemców, atakami partyzantów oraz z powodu ogólnego rozwoju sytuacji wojennej ${ }^{119}$.

Podsumowując, należy zauważyć, że problematyka imperium kolonialnego zajmowała $\mathrm{w}$ koncepcjach politycznych NSB miejsce priorytetowe przez cały okres istnienia Ruchu. W latach trzydziestych w utrzymaniu posiadłości upatrywano warunku bezpieczeństwa i dobrobytu metropolii. Po utracie kolonii dążenie do ich odzyskania było istotnym czynnikiem kształtującym inne aspekty polityki zagranicznej, którą Ruch usiłował prowadzić. Jednocześnie wyraźnie można wskazać gradację znaczenia poszczególnych elementów koncepcji. Wśród kontrolowanych terytoriów największą wagę przywiązywano do Indii Wschodnich, a znacznie mniejszą do posiadłości karaibskich (z których Mussert gotów był nawet zrezygnować). Co do preferowanych obszarów ekspansji występowały w obrębie Ruchu różnice zdań. W projektach Musserta kluczowe miejsce zajmowała Afryka, a w koncepcjach Rost van Tonningena - Europa Wschodnia.

115 J.L. Foray, op. cit., s. 36-37.

116 I nota Musserta do Hitlera z 27 sierpnia 1940 roku, s. 24.

117 G. von Frijtag Drabbe Künzel, 'Germanje': Dutch empire-building in Nazi-occupied Europe, „Journal of Genocide Research” 19, 2017, nr 2, s. 241, 249-250.

118 J.L. Foray, op. cit., s. 44-45; G. von Frijtag Drabbe Künzel, op. cit., s. 246.

119 G. von Frijtag Drabbe Künzel, op. cit., s. 250-251. 


\section{$* * *$}

Przedstawione rozważania potwierdzają, że NSB wypracował własną koncepcję polityki zagranicznej. Można ją podsumować następująco: 1. Niderlandy powinny przyczyniać się do utrzymania europejskiej dominacji na świecie; 2 . w tym celu powinny wspierać dominującą pozycję Niemiec jako najsilniejszego kraju europejskiego; 3. stosunki z Niemcami powinny zarazem pozostać oparte na zasadzie niezależności państw narodowych; 4. docelowym państwem narodowym są Wielkie Niderlandy („Dietsland”), grupujące Holendrów, Flamandów i Burów; 5. Niderlandy do przetrwania i rozwoju potrzebują posiadłości kolonialnych. Te elementy pozostały w zasadzie niezmienne przez cały okres istnienia Ruchu.

Szczegóły koncepcji ewoluowały — na przykład co do określenia głównego przeciwnika, jeśli chodzi o stopień powiązania i zależności od Niemiec czy w kwestii kierunków polityki kolonialnej. Zmiany były wymuszane przede wszystkim czynnikami zewnętrznymi, w tym zwłaszcza wybuchem i przebiegiem wojny oraz wynikającym z niej rozwojem sytuacji geopolitycznej. W pewnym zakresie modyfikacje były również rezultatem sytuacji wewnętrznej w kraju, a w szczególności skali zagrożenia pozycji politycznej Ruchu przez stronników SS. Pod częścią wspomnianych założeń bez wątpienia mogliby się podpisać ówcześni niderlandzcy politycy reprezentujący inne ugrupowania - dotyczy to zwłaszcza zagadnień kolonialnych. Część była także podzielana przez polityków zagranicznych (zwłaszcza flamandzkich zwolenników zjednoczenia). Koncepcja polityki zagranicznej NSB z pewnością nie była jednak kopią programu NSDAP, mimo pewnych podobieństw ${ }^{120}$.

Trzeba zauważyć, że część założeń programowych pozostawała na wysokim stopniu ogólności — chociażby zagadnienia kształtu współpracy gospodarczej w „nowej Europie”. Zarazem pojawiały się propozycje bardzo szczegółowe i nierealistyczne. Dla przykładu projekty kolonizacji Nowej Gwinei czy „plan Musserta" dotyczący Gujany i towarzyszące mu przesiedlenia uderzająco nie liczą się z rzeczywistymi uwarunkowaniami politycznymi, geograficznymi i gospodarczymi. Podobnie sama koncepcja Związku Państw Germańskich ignorowała układ sił w polityce niemieckiej oraz rzeczywiste cele i dążenia III Rzeszy.

Nie należy jednak tracić z pola widzenia, że koncepcja polityki zagranicznej Ruchu nigdy nie wymagała rzeczywistej operacjonalizacji. Ostatecznie ani w latach trzydziestych, ani po rozpoczęciu okupacji NSB nie sprawował realnej władzy. Przed wojną nie wchodził w skład żadnej koalicji rządzącej, a po jej wybuchu, mimo pozorów znaczenia, pozostał jedynie pionkiem w rozgrywce poszczególnych ośrodków władzy okupacyjnej ${ }^{121}$.

120 Występowały one także w odniesieniu do polityki wewnętrznej. Zob. J. Meyers, op. cit., s. $64-65$.

121 I. Schöffer, op. cit., s. 82. 


\section{Bibliografia}

\section{Źródła}

Genechten R. van, Dietsche verbondenheid, Leiden 1938.

Mussert A., Mussert spreekt, przemówienie z 21 września 1934 roku, Utrecht 1934.

Mussert A., De Verenigde Staten van Guyana. Het Joodsch nationaal tehuis, Leiden 1939.

Mussert A., Waar het om gaat. Danzig en de Corridor, „Volk en Vaderland” 1.09.1939.

Mussert A., Zinloos geofferd. De vernietiging van de Indische kruisers, „Volk en Vaderland” 15.02.1942.

Rijksinstituut voor Oorlogsdocumentatie, Vijf nota's van Mussert aan Hitler over de samenwerking van Duitschland en Nederland in een bond van Germaansche volkeren 1940-1944, Den Haag 1947.

Winkler P.E., Blank Nieuw-Guinea. Een nieuw stamland voor het Nederlandsche volk, Utrecht 1935.

\section{Archiwum Niderlandzkiego Instytutu Badań nad Wojną, Holokaustem i Ludobójstwem (NIOD) w Amsterdamie}

20-punktowy Program NSB z objaśnieniem, 1932, NIOD 123/1.

Raport dotyczący werbunku żołnierzy z 14 kwietnia 1934 roku, 1934, NIOD 123/4.

Projekt schematu zarządu posiadłościami kolonialnymi, 1936, NIOD 123/59.

Raport Samuela van Lunterena z 1938 roku, 1938, NIOD 123/81.

Przemówienie Meinouda Rost van Tonningena z 24 listopada 1938 roku, 1938, NIOD 169/698.

Korespondencja Pieta van Rossema do Antona Musserta z 1940 roku, 1940, NIOD 123/118.

Neerlands toekomst, broszura z przemówieniami Antona Musserta z 1940 roku, 1940, NIOD 285/32.

Przemówienie Meinouda Rost van Tonningena z 8 lutego 1941 roku, 1941, Rost van Tonningen.

Dyskusja na temat przemówienia Meinouda Rost van Tonningena z 8 lutego 1941 r., 1941, NIOD $123 / 133$.

Przemówienie Willema Kostera z lutego 1941 roku, 1941, NIOD 123/133.

List Meinouda Rost van Tonningena do Antona Musserta z 22 października 1941 roku, 1941, NIOD $285 / 11$.

Raporty na użytek NSB z 1941 i 1942 roku dotyczące sytuacji w Belgii, 1941-1942, NIOD 123/118.

Przemówienie Carolusa Huygena z 21 lutego 1942 roku, 1942, NIOD 123/393.

Over den Nederlandschen Staat in het nieuwe Europa, przemówienie Antona Musserta z 31 lipca 1942 roku, 1942, NIOD 123/167.

Przemówienie Antona Musserta z 13 grudnia 1942 roku, 1942, NIOD 123/393.

\section{Opracowania}

Balicki J., Bogucka M., Historia Holandii, Wrocław 1989.

Foray J.L., An old empire in a new order: The global designs of the Dutch Nazi Party 1931-1942, „European History Quarterly” 43, 2013, nr 1.

Frijtag Drabbe Künzel G. von, 'Germanje’: Dutch empire-building in Nazi-occupied Europe, „Journal of Genocide Research" 19, 2017, nr 2.

Furlong P.J., Family ties? Afrikaner nationalism, pan-Netherlandic nationalism and neo-Calvinist „Christian nationalism”, „New Contree: A Journal of Historical and Human Sciences for Southern Africa” 2015, nr 74.

Havenaar R., Anton Mussert, verrader voor het vaderland. Een biografische schets, Den Haag 1984. 
Havenaar R., De NSB tussen nationalisme en 'volkse' solidariteit: De vooroorlogse ideologie van de Nationaal-Socialistische Beweging in Nedeland, Den Haag 1983.

Homan G.D., „Patriotic” traitors: Dutch national socialists in peace and war, „Pro Rege” 1991, nr 4.

Kołek P., Polityka zagraniczna Holandii w latach 1945-2012, Toruń 2013.

Longerich P., Himmler. Buchalter śmierci, przeł. S. Szymański, J. Skowroński, Warszawa 2014.

Łaptos J., Historia Belgii, Wrocław 1995.

Meek H., Nieuw-Guinea als utopie. Nederlandse kolonisatieplannen 1920-1940, „Tijdschrift voor Geschiedenis" 2009, nr 3.

Meyers J., Mussert. Een politiek leven, Amsterdam 1984.

Schöffer I., Het nationaal-socialistische beeld van de geschiedenis der Nederlanden, Utrecht 1978.

Slaa R. te, Klijn E., De NSB. Ontstaan en opkomst van de Nationaal Socialistische Beweging 19311935, Amsterdam 2009.

Wever B. de, Groot-Nederland als utopie en mythe, „Bijdragen tot de Eigentijdse Geschiedenis” 1998, nr 3.

Wils L., De Groot-Nederlandse beweging, „Tijdschrift over de Geschiedenis van de Vlaamse Beweging" 2005, nr 1.

Zee S. van der, Voor Führer, volk en vaderland. De SS in Nederland, Hilversum 2008.

\section{Źródła internetowe}

http://www.nlverkiezingen.com.

https://www.parlement.com/id/vg9fgopw85zk/a_a_anton_mussert.

\section{THE NATIONAL SOCIALIST MOVEMENT (NSB) IN THE NETHERLANDS AND ITS CONCEPT OF FOREIGN POLICY, 1931-1945}

\section{Summary}

The National Socialist Movement in the Netherlands (NSB), established in 1931, was the most important collaborating political party in that country during World War II. The movement developed its own concept of foreign policy, which differed from the policy of Nazi Germany. The party aimed at upholding Europe's dominant position in the world. To achieve that, the European system should be reconstructed and Germany's leading role within it needed to be acknowledged. Close cooperation of nation-states should form the basis of the continental order. The prospective Dutch national state - "Dietsland" - was to be composed not only of the Dutch people, but also of the Flemish and the Afrikaners. This united country was also supposed to secure its colonial possessions overseas. This concept of foreign policy was maintained during the whole period of the movement's existence, even though some minor modifications did occur in the meantime.

Keywords: Anton Mussert, fascism, the Netherlands, NSB, foreign policy.

Paweł Kołek

pawelkolek@o2.pl 